\title{
The SWOT analysis for sustainable MSWM and minimization practices in Turkey
}

\author{
Aydin Temel F. ${ }^{1,}{ }^{*}$, Konuk N. ${ }^{2}$, Turan N.G. ${ }^{3}$, Ayeri T. ${ }^{3}$ and Ardali Y. ${ }^{3}$ \\ ${ }^{1}$ Department of Environmental Engineering, Engineering Faculty, Giresun University, TR-28200, Giresun, TURKEY \\ ${ }^{2}$ Department of Geomatic Engineering, Engineering Faculty, Ondokuz Mayıs University, 55200, Samsun, Turkey \\ ${ }^{3}$ Department of Environmental Engineering, Engineering Faculty, Ondokuz Mayıs University, 55200, Samsun, Turkey \\ Received: 20/12/2016, Accepted: 07/03/2017, Available online: 24/01/2018 \\ *to whom all correspondence should be addressed: e-mail: fulya.temel@giresun.edu.tr
}

\begin{abstract}
One of the most important environmental problems is municipal solid waste management (MSWM) as a result of the rapid rise in waste generation due to industrialization, economic development, urbanization, and rapid population growth in Turkey. The collection, transportation, and disposal of solid waste are conducted by municipal authorities of Turkey. The waste management problem is getting more serious due to some reasons such as lack of enforcement of regulations, weak technical and financial resources, poor infrastructure, insufficient policies and deficiency of political priorities, poor coordination between authorities. Hence, despite the legislation, municipal solid wastes are managed in an unscientific manner by the municipalities. The SWOT analysis is a perfect tool to discover the possibilities and ways for successfully implementing the MSWM. In this study, SWOT analysis carried out both negative and positive concerns of MSWM. A successful strategic management has been identified from the SWOT analysis for the municipal solid wastes. Further, the study proposes options based on SWOT analysis approach to improve in available waste management practices that could also be adopted by other countries to decrease the adverse effect of MSW on human and environment health.
\end{abstract}

Keywords: solid waste, management, Swot analysis, sustainability, minimization.

\section{Introduction}

Urbanization, industrialization, and enhanced living standards rise the complexity and quantity of generated MSW (Rathi, 2007; Gupta et al., 2015). MSW generally contains degradable (food waste, paper and cardboard, yard and textiles waste), partially degradable (disposable napkins, sludge, and wood), and non-degradable (plastics, dust, leather, ash, rubbers, glass, metals, and electronic waste) (Herat, 2009; Jha et al., 2011). Currently, almost 1.3 billion tonnes of MSW is generated in the world and it is expected to icrease to 2.2 billion tonnes by 2015 (World Bank, 2012).
MSWM is mainly consisting of MSW generation, sorting, collection, transportation and disposal. In practice, MSWM is carried out by the cooperation of households, local authorities and central government (Chen, 2010). Households are responsible for sorting of MSW as recyclables and others at home. Households should also throw the recyclables and other wastes into the containers at a given time, separately. Local authorities are responsible for supporting the waste containers, transporting generated wastes, processing recyclable wastes and disposal of the other wastes. Central government is responsible for the planning and making of appropriate environmental policies and strategies. However, MSWM is getting more severe due to some reasons such as inefficient financial and technical capacity, poor infrastructure and land use, weak coordination between authorities, defficient policies and lack of enforcement of regulations (Kumar et al., 2009).

In recent years, many researchs have evolved to adopt decision support tools to design MSWM systems. A SWOT analysis is one of the tool designed to be used in the preliminary steps of desicion-making and as a precursor to strategic management planning on the other (Srivastava et al, 2005). SWOT is an acronym for weaknesses, strengths, opportunitis and threats. All plans and projests have their strengths, weaknesses, opportunities and threats (Srivastava et al., 2008). Strenghts and weaknessees are internal (controllable) factors, while opportunities and threats are external (uncontrollable) factors.

The SWOT analysis is a tool to discover the possibilities and ways for successfully implementing the MSWM. The aim of the study is to investigate the existing MSWM practices in Turkey to recognize factors that are liable for ineffective management. A strategic MSWM was identified from the SWOT analysis for the MSW in Turkey.

\section{Methodology}

In this study, SWOT (Strengths, Weaknesses, Opprtunities and Threats) analysis was carried out to select the desirable strategies in MSW management of Turkey. The internal and external factors that are important to achieving the objective were identified. The factors are: 
- Internal factors - The strengths and weaknesses presented by the internal to the management.

- External factors - The opportunities and threats presented by the external environment.

According to the SWOT, strengths are the inherent abilities to compete and grow strong. Weaknesses are the inherent deficiencies that inhibit growth and survival. Opportunities are the good chances for growth. Threats are externally wielded challenges, which might suppress inherent strengths, accelerate weakness and stifle opportunities from being exploded (Jasiulewicz-Kaczmarek, 2016).

The research methodology used consist mainly of four steps (Fig. 1):
- Investigation of related legislation, regulations and reports.

- Identification of relevant factors of the internal and external environments by the baseline survey using an activity worksheet. Activity worksheet of SWOT analysis is given in Table 1 . As seen in Table 1, 7 internal factors and 6 external factors have been identified for the SWOT analysis.

- Evaluation of the strengths, weaknesses, opportunities and threats based on results.

- Proposing policy recommendation based on the SWOT analysis.

Table 1. Activity worksheet of SWOT analysis

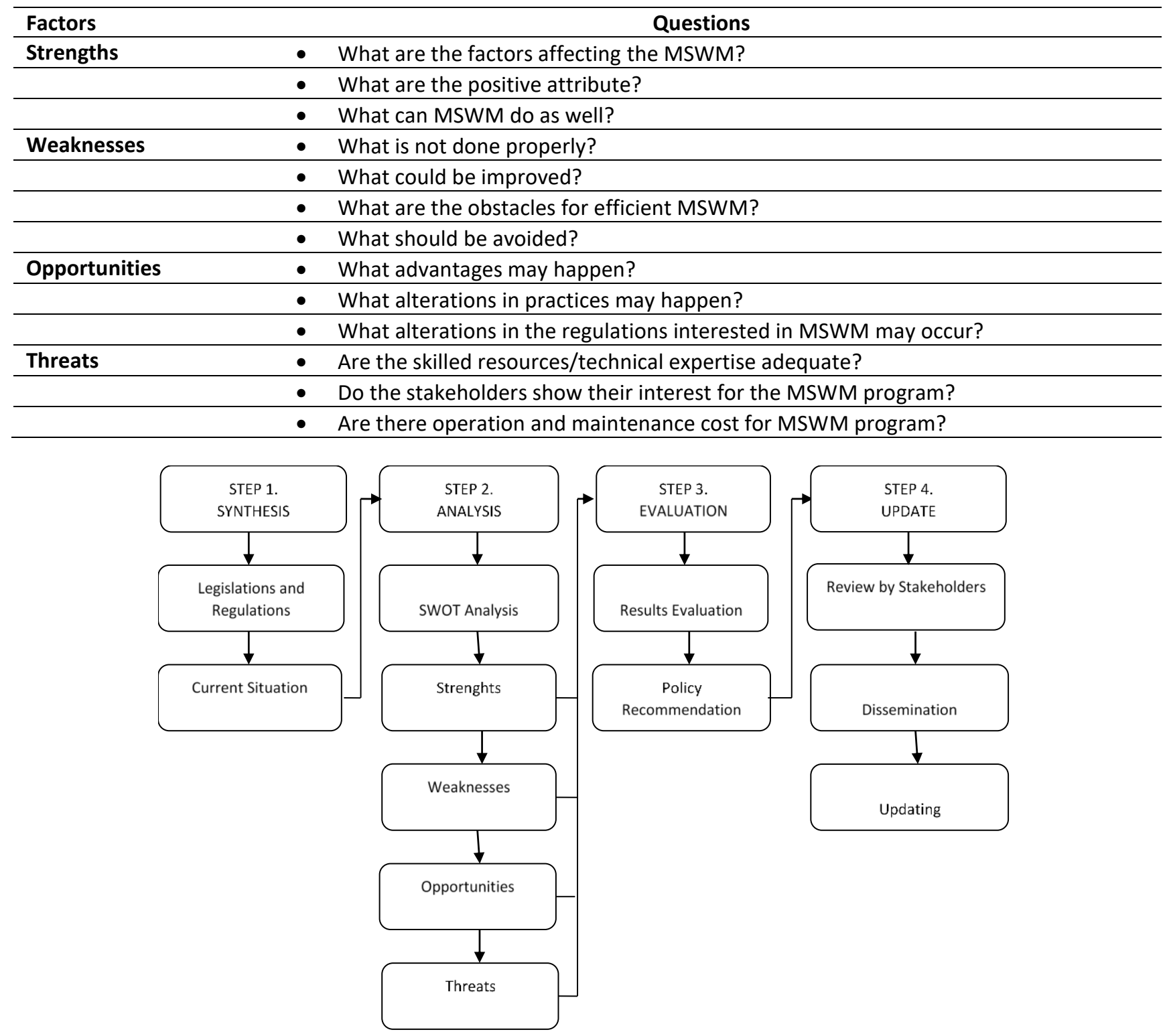

Figure 1. General methodology used for the development of the MSWM

\section{Results and discussion}

\subsection{Situation of MSWM in Turkey}

Waste generation in Turkey increased by the primary factors such as rapid population growth, urban strawling, and change in consumption style. The Turkish State Statistical Institute has compiled statistics about MSW since 1994. According to the Turkish State Statistical Institute (TUIK, 2017), the annual quantity of MSW generated in Turkey increased from 17 million tonnes in 
1994 to 28 million tonnes in 2014 (Fig. 2). However, waste generation rate decreased year by year, because of scavengers who are segregate and collect recyclable matters at collection points and generation sources. MSW generation rate per capita is approximately $1.08 \mathrm{~kg} /$ day in 2014 (TUIK, 2017). The changing of MSW generation rate per capita is shown in Fig. 3.

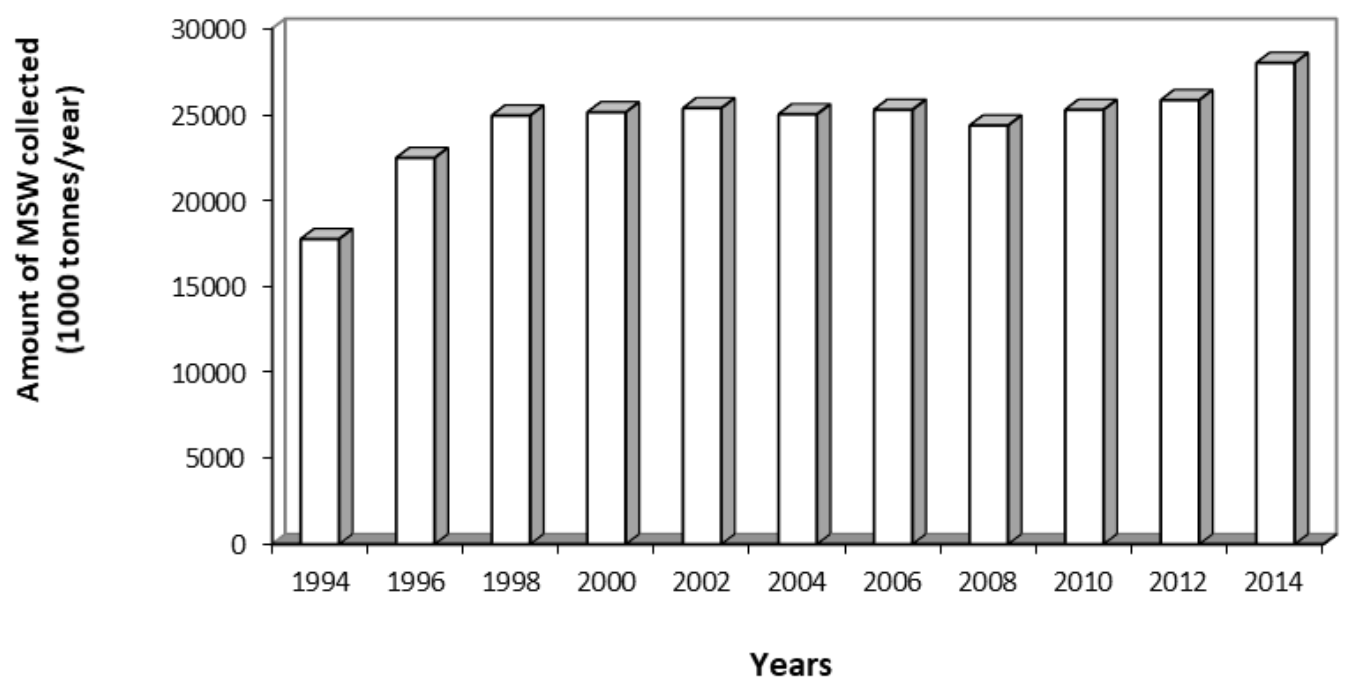

Figure. 2. The quantity MSW collected in Turkey

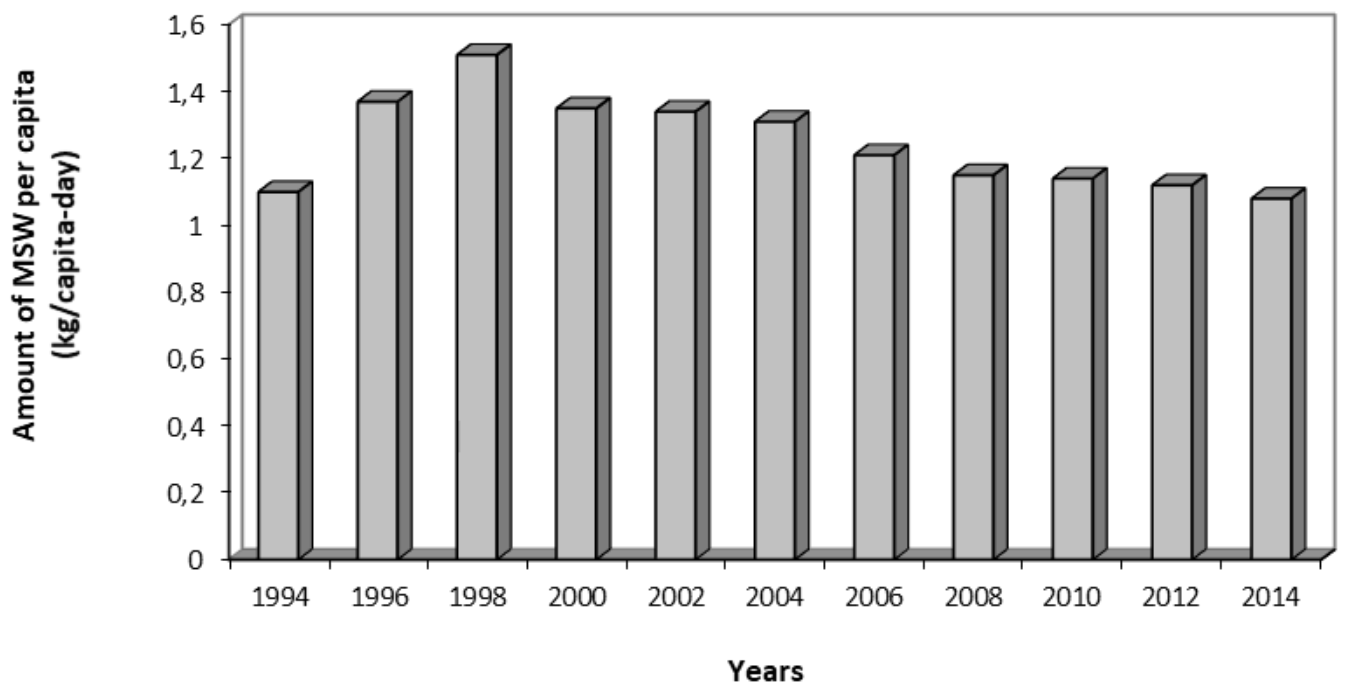

Figure 3. The quantitiy of MSW per capita (kg/capita-day)

The characteristics of MSW change from place to place. The main fraction of MSW is biodegradable materials (50\%$60 \%)$, recyclables (20\%-30\%) and inerts (10\%-20\%) in urban areas. The percentage of recyclables (cardboard, paper, plastics, metals and glass) in urban areas is higher than that of in rural areas. In rural areas, biodegradable materials are the main fraction of MSW.

MSWM flow in Turkey is given in Fig. 4. MSW collection starts after residents put generated waste in a container at designated locations. In most of the urban areas, MSW are collected together with recycables, biodegradables and inerts at the same container. Before waste is being collected by the municipality staff, recyclable wastes are sorted out from the containers by scavengers or waste pickers. The containers used is not properly designed and maintained in rural areas. The collection day and time is varied from municipality to municipality. The collected MSW is then transported to disposal areas.

In Turkey, the main MSWM method is sanitary landfilling. However, open dumping is used for MSW disposal in many municipalities. The Turkish State Statistical Institute's 2014 data base, MSW disposal methods in Turkey is given in Fig. 5. In 2014, 17807424 tons of MSW was disposed to sanitary landfills whereas, 9935600 tons of MSW was disposed to open dumping area. On the other hand, 153885 tons of MSW was incinerated in open area, landfilled, disposed to surface waters without any control (TUIK, 2017). 


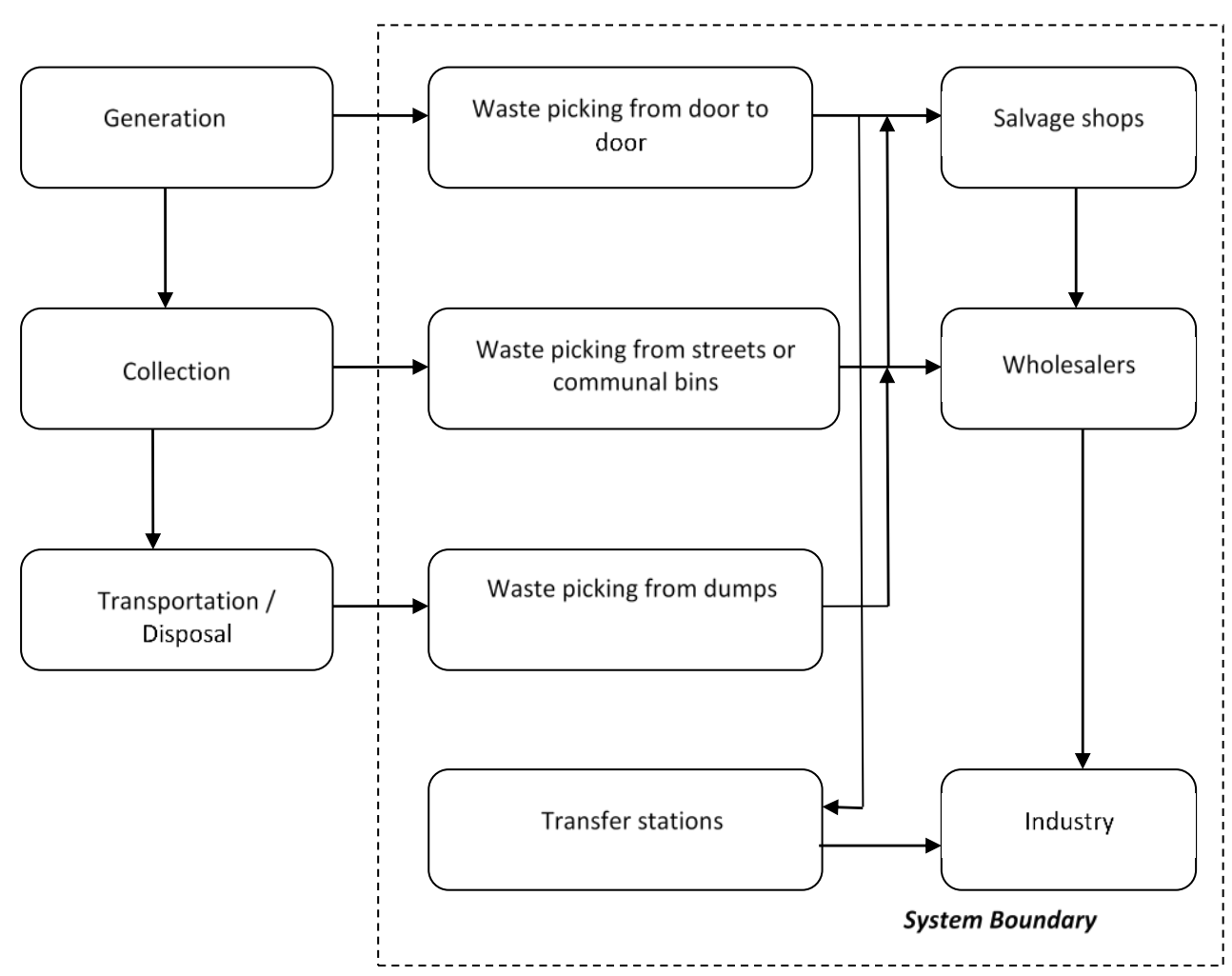

Figure 4. MSWM flow of Turkey

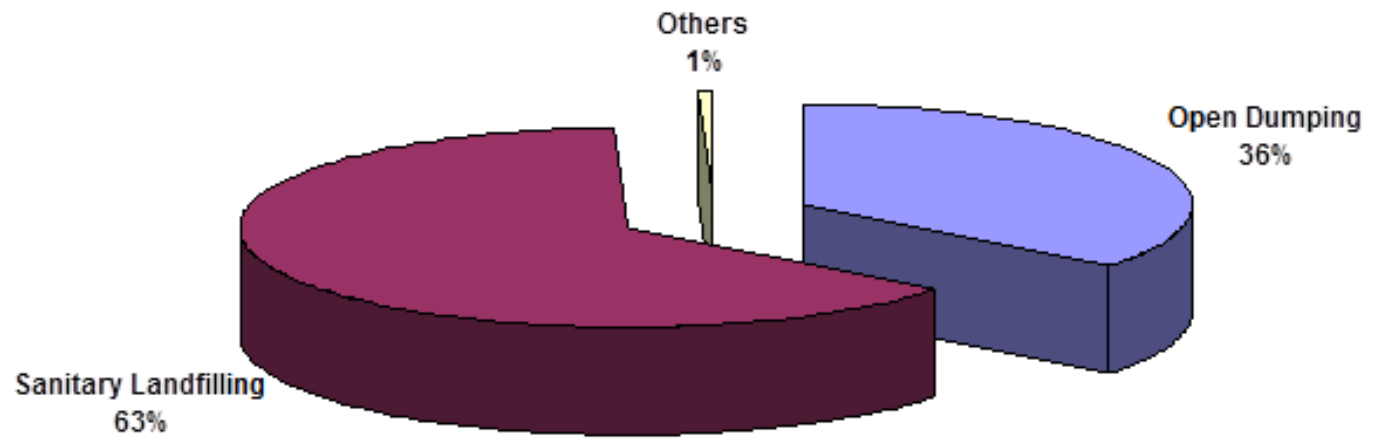

Figure 5. MSW disposal methods of Turkey

\subsection{SWOT analysis for MSWM in Turkey}

The SWOT analysis was applied to develop a strategic action plan for sustainable MSWM in Turkey. It aimed at identifying the internal and external factors that might have an impact on the proposed MSWM programme. The factors are spesific and evaluative, becuse its findings were used in subsequent strategic planning efforts (Srivastava et al., 2005). Regarding the SWOT analysis, the factors observed were given in Table 2. It can summarize some positive and negative aspects related to implementation of SWOT, as well as the necessities that drive the process. When considered the all factors of weaknesses, strengths, opportunities and threats, some possible actions should be noted:

i) Environmental actions: Enhancing environmental education and conscious, creating more conscious citizens and consumers; creation of natural resources savings policies; preventing environmental pollution such as water pollution, air pollution, soil polltion and etc.

ii) Social actions: Creation of policies for public awareness; creation of public participation for an efficient MSWM; increasing good communication and consolidating partnerships among government and community for MSWM.

iii) Economic actions: Creation of policies for materials reutilization; savings through the use of recycled materials; creation of advertising campaigns and installation of collection points for recyclable waste.

iv) Strategic actions: General enforcement of the regulation 2 April 2015/29314 (The Regulations of Waste Management); qualification of the companies (producers, 
distributors, importers, retailers) to meet the demands of the community; partnerships among government and companies cited above that enable the collection of recyclable waste at an acceptable cost and efficiency and; promoting incentives for companies (Guarnieri et al., 2016); decentralization of MSWM services (Srivastava et al., 2005).

Table 2. SWOT analysis for MSWM in Turkey

\begin{tabular}{|c|c|}
\hline Strengths & Weaknesses \\
\hline $\begin{array}{l}\text { - } \quad \text { Active community participation. } \\
\text { - } \quad \text { Students are motivated by the subject in schools. } \\
\text { - Municipalities carry out recycling activities such } \\
\text { - } \quad \text { as award and training programs. }\end{array}$ & $\begin{array}{l}\text { - } \quad \text { Lack of awareness. } \\
\text { - } \quad \text { Lack of environmental knowledge. } \\
\text { - } \quad \text { Lack of waste segregation at source. } \\
\text { - } \quad \text { Technical deficiency. } \\
\text { - } \quad \text { Economic problems. }\end{array}$ \\
\hline Opportunities & Threats \\
\hline $\begin{array}{l}\text { - Interest for the environmental image and } \\
\text { education. } \\
\text { - Participation in waste prevention activities. } \\
\text { - Materials which are available for recycling } \\
\text { industry. } \\
\text { - Communication tools. }\end{array}$ & $\begin{array}{l}\text { - } \quad \text { Loss of interest. } \\
\text { - } \text { Motivation. } \\
\text { - } \quad \text { Technical innovation. } \\
\text { - Administration. }\end{array}$ \\
\hline
\end{tabular}

\section{Conclusions}

The SWOT analysis is a perfect tool to discover the possibilities and ways for successfully implementing the MSWM. The SWOT analysis consists in a systematic assessment of all activities with influence on the MSWM. In this study, the SWOT analysis carried out both negative and positive concerns of the MSWM. When considered the all factors of weaknesses, opportunities and threats, strengths, some possible actions such as environmental, social, economic and strategic actions were identified. Lines of actions proposed include the creation of specific plans, establishing new management models, creation of policies for public awareness and participation, updating of legislations and regulations.

\section{References}

Chen C.C. (2010), A performance evaluation of MSW management practice in Taiwan, Resources, Conservation and Recycling, 54, 1353-1361.

Guarnieri P., Silva L.C. and Levino N.A. (2016), Analysis of electronic waste reverse logistics decisions using Strategic Options Development Analysis methodology: A Brazilian case, Journal of Cleaner Production, 133, 1105-1117.

Gupta N., Yadav K.K. and Kumar V. (2015), A review on current status of municipal solid waste management in India, Journal of Environmental Sciences, 37, 206-217.

Herat S. (2009), Electronic waste: an emerging issue in solid waste management in Australia, International Journal of Environmental Waste Management, 3 (1/2), 120-134.

Jasiulewicz-Kaczmarek M. (2016), SWOT analysis for Planned Maintenance strategy-a case study, IFAC-PapersOnLine, 49(12), 674-679.
Jha A.K., Singh S.K., Singh G.P. and Gupta P.K. (2011), Sustainable municipal solid waste management in low income group of cities: a review. International Society for Tropical Ecology, 52(1), 123-131.

Kumar S., Bhatattacharyya S.K., Vaidya A.N., Chakrabarti T., Devotta S. and Akolkar A.B. (2009), Assessment of the status of municipal solid waste management in metro cities, state capitals, class I cities, and class II towns in India: and insight, Waste Management, 29(2), 883-895.

Rathi S. (2007), Optimization model for integrated municipal solid waste management in Mumbai, India, Environment and Development Economics, 12, 105-121.

Srivastava P.K., Kulshreshtha K., Mohanth C.S., Pushpangadan P. and Singh A. (2005), Stakeholder-based SWOT analysis for successful municipal solid waste management in Lucknow, India, Waste Management, 25, 531-537.

TUIK (2017), Municipal Waste Statistics, Turkish Statistical Institute,

https://biruni.tuik.gov.tr/medas/?kn=119\&locale=en

(Date of access: 16.02.2017)

World Bank (2012). What a Waste: A Global Review of Solid Waste Management, Urban Development and Local Government Unit, The World Bank, Washington D.C., USA. 